\title{
Redistribution of salary or professional recognition? The difficult construction of a profession, the Peruvian nursing
}

\author{
Redistribuição de salário ou reconhecimento profissional? A difícil \\ construção de uma profissão, a enfermagem peruana
}

Juan Arroyo-Laguna (https://orcid.org/0000-0002-3183-4046) ${ }^{1}$

\footnotetext{
${ }^{1}$ Facultad de Ciencias Sociales. Pontificia Universidad Católica del Perú. Av. Universitaria 1801, San Miguel. 15088 Lima Peru. arroyo.juan@pucp.pe
}

\begin{abstract}
The study presents the current profile of Peruvian nursing, its professional construction and its dilemmas, emphasizing its socio-cultural features. To this end, an extensive literature was reviewed, interviewing nurses in key positions and analyzing secondary source data. This stu$d y$ keeps its distance from other studies on health care professions as a workforce, to analyze the low social legitimacy of the nursing profession despite being the great operator of health care services in Peru. This resulting psychological overload, additionally to the work overload is reflected in job dissatisfaction, stress, burnout, intention of changing careers, and a strong desire to migrate. As a result, Peruvian nursing has opted for three alternatives: a) resilience, which means to adapt to this unfavorable situation; $b$ ) abandoning the profession, or leaving the country; and c) reaction, which gathers all manifestations of the profession against abandonment, informality, and mediocrity. In conclusion, the biggest challenge of professions given low social value is the recognition and not only the salary redistribution. This significant challenge for Peruvian nursing does not mainly relate to legal professionalization, but professionalism, which must result in greater legitimacy and autonomy.
\end{abstract}

Key words Nursing, Health Services Administration, Nursing Research, Professional Autonomy
Resumo $O$ estudo apresenta o perfil atual da enfermagem peruana, sua construção profissional e seus dilemas, enfatizando suas características socioculturais. Para tanto, foi realizada extensa revisão de literatura, entrevistas com profissionais de enfermagem em posições-chave e análise de dados de fontes secundárias. O estudo distancia-se dos estudos das profissões da saúde como força de trabalho, a fim de analisar a baixa legitimidade social da profissão de enfermagem, apesar de ser a grande operadora de serviços no Peru. Isso produz uma sobrecarga psicológica, que se soma à sobrecarga de trabalho e se reflete em insatisfação no trabalho, estresse, burnout, desejo de mudar de carreira ou migrar. Diante disso, a enfermagem peruana optou por três saídas: a) resiliência, que representa adaptação; b) abandono, ou saída do país ou profissão; e c) a reação, que agrupa todas as manifestações contra o abandono à informalização e à mediocrização. Conclui-se que as profissões de baixo valor social têm como desafio central o reconhecimento profissional e não apenas a redistribuição salarial. Esse desafio central da enfermagem peruana não está centralmente ligado à sua profissionalização legal, mas ao seu profissionalismo, que trará maior legitimidade e autonomia.

Palavras-chave Enfermagem, Administração de Serviços de Saúde, Ocupações em Saúde, Pesquisa em Enfermagem, Autonomia Profissional 


\section{Introduction}

This article covers a study on the situation, nature and trends of Peruvian nursing and its professional training in the Peruvian context, which scarcely recognizes its work.

Nursing has always been analyzed as a workforce, but little as a social group. That is why sociodemographic reports or studies on labor markets or on nursing training are abundant. However, figures on availability, density, distribution, number of enrollments, alumni, specialties, labor regimes, fail to explain the background of its behavior. An objectivist approach to the professions does not take into account the sociocultural characteristics of the professions, their motivations, satisfaction and identity that shape the professions. As we will see, Peruvian nursing is practiced under incomplete social protection policies and a non-universal health system, but also under a marked patriarchal structure and a professional undervaluation, which has over-determined its number, gender, recognition, power, professional qualifications and its function in the health care services. This interaction between nursing and its context has resulted in laws of movement governing its reproduction dynamics.

Since this interrelation is not stable, the profession always moves around solving the dilemmas that it has to solve. The first was the step from amateur nursing to nursing with institutionalized training, at the beginning of the 20th century, with the founding of the first School in 1907. The second was the conversion in 1973 into a lay profession, when the religious congregations that led their Schools began their retirement. The third was the birth of nursing as a university profession, with the affiliation of the Schools to the universities between 1984-85. The fourth was the transition from a de facto profession to a profession with autonomy and full legal recognition, with the creation of the Association of Nurses in 1978. Each of these milestones has been an advance.

However, there was a continuum throughout its history: an underappreciation and undervaluation of their work. Fabiola Tavera, one of the founders of Peruvian nursing, explained this problem: "Nursing has suffered lack of understanding during its history, a great odyssey full of misfortunes and triumphs, romances and adventures; and the most important is that it has been the history of a professional group, whose status was marked by the prevailing norms of humanity that have given this noble profession an undeserved low valuation, very difficult to overcome"1 (p.26). She refers to a sector of public opinion that insists in considering nursing as an ancillary support group, almost a volunteering focused on first aid and low complexity tasks ${ }^{2}$. This obviously affects the nurse's subjectivity. It is not a coincidence the frequency with which you can find studies on menial work, stress and burnout in nursing. Paraphrasing Nancy Fraser ${ }^{3}$, we might say that its historical challenge is not redistribution but recognition. It is not that there are no reasons for better salaries. But the lack of the latter results in the first.

Next, we will present some indicators of the profile of Peruvian nursing, before analyzing the dynamics that today leads it to three scenarios. We have conducted a wide literature review, interviews with nurses in key positions, and carried out the analysis of the existing data. The objective is to approach the nursing process and sense.

\section{Profile of the Peruvian Nursing}

There are 35 legally recognized professions in Peru. However, not all comply with the classical characteristics of professions. According to Freidson ${ }^{4}$, a profession is an occupation that has control over its own work, organized by a special set of institutions supported, in part, by a particular expertise and service ideology. For Andrew Abbott ${ }^{5}$, professions are exclusive occupational groups applying somewhat abstract knowledge to particular cases. For Machado 6 , "a profession is defined as such, when there is a specific body of knowledge acting in a social and organized reality". Turne \& Hodge $^{7}$ operationalized four requirements of professionalization: a) the degree of depth of theory and practice; $b$ ) the degree of monopoly; c) the degree of external recognition; and d) the degree of organization. Which is the case of Peruvian nursing? Does it have these four elements?

This is obviously related to a great international debate about those professions, which, according to some authors, should be considered as semi-professions ${ }^{8-11}$. Different researchers have pointed out several gaps in these cases: either they do not hold a monopoly over their field of work or they lack a scientific development or do not have sufficient social recognition.

Regarding Peru, a sector of public opinion and the State consider nursing as a support group for the medical profession, focused on the care task with complete disregard of their training for primary health care; an occupational group that 
does not require a high level of professionalization nor does it demand the development of the health care sciences, a volunteering rather than a scientific-technical work; a professional group that does not consequently deserve higher, or even middle, pay levels. Peruvian society does not pay the generated public value, it pays the acquired status. Let's see some of the characteristics of its profile.

\section{Staffing and expanding availability}

Considering the health care professions in Peru, nursing is the most numerous and in significant expansion. Nursing supports a large part of the health care system operations since it is a full-time profession; unlike physicians, who work part-time. As to June 2017, Peru's population was 31,2 million, and 265,460 inhabitants represented its health care workforce. From this total devoted to health care, 44,790 were nurses in 2017 , that is, $16.9 \%$. Breaking down the total number of nurses, 29,181 (65\%) are working for the Ministry of Health and 11,196 (24.9\%) for the Social Health Insurance Institute (ESSALUD). This means that $90 \%$ of nurses work for the public sector ${ }^{12}$. Most nurses do not work in the private sector, but they go together with the current increasing trend of private hospitals and insurance companies.

The number of nurses has grown exponentially. In 1980, there were 10,665; in 1990, the number was 17,640 reaching 29,625 in 2010 ; and then 44,790 in 2017. From 1981 to 2017 the population rose by $75.8 \%$, and nurses by $319 \%$. The other health care professionals grew less. Thus, nurses have become the most numerous professional group in the Peruvian health sector, although not the most powerful. The trend is to continue expanding: since 2012, it has become the profession with the highest annual increases, surpassing the physicians, before the largest and fastest expansion professional group. This increase has impacted positively on the availability of nurses (14,1/10,000 inhabitants in 2017) and the density of the health care staff, which is 31.9 (including physicians, nurses and obstetricians)/10,000 inhabitants ${ }^{12}$. This does not mean that the problem of quantity has been solved: for a country with a rugged geography and poor territorial connection, its standards must surpass those set by the WHO.

\section{Progressive distribution of nursing}

The problem is no longer focused on the staff availability or density but on the still persistent concentration of health care professionals in intermediate cities, notwithstanding, advances in the staff distribution were made. Only 3 out of 26 existing regions in Peru had availability of nurses above that of Metropolitan Lima 14 years ago, and today there are 19. In 2004, Lima had a $40.23 \%$ of nurses while in 2017 reached only $24.7 \%{ }^{12,13}$. In the last ten years, to cover the gap in the poorest regions of the Peruvian highlands it has gained particular importance. Consequently, the first places of availability were taken by largely ignored regions such as Apurímac (23.8), Ayacucho (18.9), and Huancavelica (16.9). However, there are still backward regions such as San Martin (6.44), Piura (6.37), and Loreto (7.56).

The distribution of nurses according to poverty quintiles has moved favoring the facilities in areas of poverty. In 1992 the availability of nurses in quintile 5 (extreme poverty) was $1.27 / 1,000$ inhabitants; in quintile $3,4.04$; and in quintile 1 (acceptable social situation) 8.35. This inequality partially changed in 2004 when the availability of nurses in quintile 5 was $7.49,6.30$ in quintile 3 , and 10.47 in quintile $1^{13}$. The latest data, from 2017 , shows that $17.9 \%$ of nurses work in quintile $1,19.4 \%$ in quintile $2,19.8 \%$ in quintile $3,14.5 \%$ in quintile 4 , and $28.1 \%$ in quintile 5 . The combination of centralism and inequality has been gradually reversed, in which the poorest quintile was short staffed. The indicator that remained unchanged was the distribution of nurses by care levels.

The Peruvian health system has 18,645 health facilities. From this total, 606 are hospitals, 18 are specialized institutes, 2,296 health care centers, 8,002 health care posts, 6,943 medical offices and private facilities, and 600 dental centers ${ }^{14}$. From the total number of facilities, only 387 belong to ESSALUD. Breaking down this, 80 are hospitals and 298 are polyclinics, medical centers and other specific modalities. In general, ESSALUD facilities are more complex than those of MINSA, which has $90 \%$ of the first and second level health care facilities. In this context, the distribution of nurses by levels of health care is key; this was not considerably altered between 2013 and 2017 MINSA maintained a $45 \%$ in the first level, $26.2 \%$ in the level 2 or intermediate, and $28.3 \%$ in the third level, the most specialized. In conclusion, the decentralization of nurses was attributable to geographical reasons, looking at 
the interior of the country, but not at the system base, while the distribution of physicians moved towards the hospital vertex. The presence of physicians at the system base suffered a partial reverse since it went from $37.4 \%$ to $40,6 \%$ in the third level and dropped from $43 \%$ to $33.9 \%$ in the first level for the 2013-2017 term. The Peruvian model redistributes downwards but to other professions.

\section{Unpaid work inside or outside the home}

The Peruvian health care system is based on the traditional Latin American segmented model, where the poorest use the health care services provided by the Ministry of Health [MINSA] and the 26 Regional Bureaus of Health; the insured workers, the Social Health Insurance (EsSalud); and the middle and high classes, the private sector. Additionally, Peru has a reduced overall expenditure on health per capita (USD 359) and a low public expenditure on health $(39.4 \%$ of the health expenditure and $2.8 \%$ of the GDP). This increases the out-of-pocket expenses in health $(28.6 \%)$ and, in general, the expenses for the unpaid housework (TDNR, in Spanish).

The Peruvian State does not have a sound public care policy in place (daycares, services for the elderly), and this means an extra burden for women. This is reflected on the eminently curative approach of the Peruvian health care system, which does not devote much attention to health prevention and promotion. The public value of care is then assumed by the families and wom$\mathrm{en}^{15}$. Nursing is small in number compared to the deficit of professional health care.

The last calculation of unpaid housework in Peru revealed that Peruvian households dedicate 545 million hours per week to domestic services in 2010. This represents $20.4 \%$ of the annual 2010 GDP. Women contributed 2.2 times more to the value of housework than men. This contribution is 4.1 times greater for meals preparation and 2.3 times greater for child and adult care ${ }^{16}$.

The massive influx of women into the work market and the population aging are a current problem that puts at risk this model. The activity rate of the female working population (PEA, after its name in Spanish) was $25.5 \%$ in 1981, while in 2004 grew to $61.6 \%$ and $2017,64 \%{ }^{17}$. People over the age of 60 represented $5.7 \%$ of the population in 1950 , but in 2018 , they reached $10.4 \%$. According to Aguirre, there is an increasing number of people that need care, and less potential caregivers $^{18}$. Now we have to take care of children and the elderly, and there is "aging within aging"19, i.e. an increase in the number of people that live longer than 80 and 85 years old. The decline in marriage and the multiplication of different types of couples and families (26.5\% of Peruvian households have a female head), as well as the opportunity to migrate to be part of the global health care networks, led to create a new public care policy. In fact, there is an ongoing progressive change of the care model that is partially taking the family out of the equation. For many, it is an opportunity to commercialize the private sphere; for others, it is a chance for new forms of sociability and social contract. Regarding the situation of nursing in Peru, the problem is that the State cannot cover the dwindling capacity of families to take on this role and historically, the State has not assumed responsibility. Therefore, the implicit public policy that confines care to families entails a burden for nursing in Peru.

\section{Precarious situation of nurses}

Most Peruvian nurses work for MINSA (Ministry of Health) under an indefinite-term contract with all social benefits guaranteed: $58 \%$ are appointed; $27 \%$ have an Administrative Service Contract (CAS, after its name in Spanish), which is a temporary contract with limited work benefits; $11 \%$ work under a contract regulated by Legislative Decree 276, which is the oldest type of contract with low salaries; and just $0.6 \%$ work under a contract governed by Legislative Decree 728 , which is the most attractive Peruvian labor regime with more beneficial salaries and work rights. The starting point of the increasing professional insecurity is found here, but it is also reflected in the salaries, which are generally low in the health care sector in comparison to regional and world standards. The highest paid nurses work in OECD countries that attract professionals from all over the world: The United States pays an annual average wage of USD 73.000 (PPP); Ireland, 64,000; Canada, 58,000; the United Kingdom, $51,000^{20}$. Every neighboring country of Peru pays nurses more; therefore, they tend to migrate abroad.

In the Peruvian public system, salary gaps are gender-based and reflect the social consideration given to the profession. The global pay gap between men and women working the same number of hours in the health care sector is $21.1 \%{ }^{21}$. In Peru, the research conducted by Sal y Rosas et al. ${ }^{22}$ concluded that the income of male physicians and nurses was $8 \%$ higher than female 
physicians and nurses. Moreover, this gap is legally established. By means of Supreme Decree No. 022 of January 2019, the Peruvian Ministry of Economy lays down the amounts for the main salaries in the health care sector, determining a base rate of USD 901 for nurses, dental surgeons, pharmaceutical chemists, obstetricians and medical technologists; and 1,601 for physicians. Therefore, a starting nurse is worth $56 \%$ of a physician, whereas more seasoned nurses in level 5 are worth $58.8 \%$ of a physician. But in reality, they receive less. The Peruvian Ministry of Labor places nurses in place 58 of the list of salaries for young professionals graduated from 2012-2016 ${ }^{23}$.

\section{Persistent feminization}

The Peruvian Association of Professional Licensed Nurses reported 86,565 members in $2017^{24}$. Given the fact that the sectoral statistics register has 44,790 nurses currently working, the difference of 41,775 does not exercise the profession, maybe because some members are still registered despite their death, or they have already retired, or migrated abroad, or they are unemployed or work in other sectors. Therefore, the offer of graduated nurses is higher than the demand. There is much need or potential demand, low effective demand or available positions, and a surplus of offers related to this effective demand.

Along the same patriarchal line, the work force in the health care sector is mainly female. The percentage of women has slightly increased between $2010(62.7 \%)$ and $2016(64.5 \%)^{25}$. Feminization in nursing is higher, where $89.6 \%$ of the positions are covered by women and only $11.5 \%$ by men. These proportions have remained unchanged in the last decade ${ }^{25}$. In the Americas, the percentage of female nurses is $86 \%$ and male nurses $14 \%{ }^{21}$. All around the world, nursing is socially considered a woman's career. And a special emphasis is given to this in Ibero-America. Paradoxically, there is a progressive feminization of all health care professions that were traditionally male professions, such as medicine and dentistry; however, there is no masculinization process in professions that are traditionally female professions, such as nursing and obstetrics. In 2010, $31.9 \%$ of MINSA physicians were women and it increased to $37.2 \%$ in 2016 .

\section{Key rol in the health care services}

The current tradition in the health care sector of Peru assigns an organizational role in the operation of services to nursing, thus becoming a full-time mono-occupational profession, whereas physicians can take on multiple jobs and an extensive day regime. The nursing professionals, as well as other health care professionals and technicians, maintain the services, whereas physicians can aspire to an optimal performance of their working day by having multiple jobs.

On average, unlike the very low percentage of nurses $(7.9 \%), 44.1 \%$ of physicians state that they take on health care duties in other institutions. This is why physicians declare that they work more hours per week (52) than nurses $(41)^{26}$. This increases the pay gap legally established between physicians and nurses in their home institutions. It is noteworthy that $64.3 \%$ of physicians say that they gain over USD 1,538, amount that only $6 \%$ of nurses can access. Meanwhile, $9.4 \%$ of physicians state that they earn more than USD 3,000 monthly, amount that no nurse can gain. That is not to say that physicians are well paid or that every profession should earn the same. This only shows the different strategies of each profession to reach their salary expectations, strategies that have ended up shaping the professions. The tension between their contributions to the social reproduction and their own social reproduction arises here.

\section{Increase in the number of schools, teaching without research}

Over the past three decades, Peru has lived an indiscriminate increase of new universities and schools and departments of nursing. The first two schools were founded in 1907 and 1915: Teaching Hospital at the Health Care House of Bellavista in Callao and the Central School of Nurses at the Dos de Mayo Hospital, respective$\mathrm{ly}^{27}$. In 1939, the Worker's Social Security founded the School of Nursing at the Workers' Hospital of Lima; and in 1940, the Public Charities of Callao opened the Nursing School of the Daniel Alcides Carrión Hospital, and the Police Health Care Bureau created the Health Care School for the Government and Police. The School of Nurses of the Jungle was opened in Iquitos in 1942, and the The Andean School of Female Nurses was established in Puno in 1944. Every hospital or health care provider devised their own educational system. But still there were no nursing programs in universities until 1984, where they became mandatory and their educational system fell under the control of the Ministry of Health, and not the Ministry of Education. The influence 
of the religious congregations was also decisive in each school. This nursing training system steadily developed until the 90s and has been growing exponentially ever since. In 1960, there were already 12 schools; by 1980, 28 were already established; and 45 schools existed in 2000. Today there are 71 nursing schools or departments, $57.7 \%$ of which belong to private universities.

This multiplication has led to a shortfall in the number of nursing teachers and the social acceptance of a low quality university education with very little research. Only $3.1 \%$ of the medical professionals and $0.8 \%$ of the nursing professionals are registered as researchers at the National Council for Science, Technology and Innovation ${ }^{25}$. Meanwhile, only $0.9 \%$ of nurses have published an article in an ISI, Scopus or MEDLINE indexed journal. In the case of physicians, this percentage reached $11 \%$.

The amount of nursing students is enormous. In 2004, nursing was the sixth university program with the highest enrollment $(16,700$ students $)^{28}$. According to a study conducted by Jiménez et al. ${ }^{29}$ from 2007 to 2011, an annual average of 10,742 high school graduates applied for nursing programs in public universities, whereas 5,187 , for private universities. Annually, 6,579 students are admitted to nursing programs.

Why are there so many applicants for a low-paying profession? The high level of informality and underemployment in the Peruvian society $(72.53 \%$ and $50.1 \%$, respectively) push young people to university education and to affordable programs such as nursing, since education is perceived as an excellent vehicle for social mobility. This generates groups of unemployed graduates or graduates with underpaid jobs. This demonstrates that at some point the education sector disconnected from the working world of the health care sector, since the university offer produces much more graduates and title holders than the actual health care demand ${ }^{13}$.

Since 1995, private investment has been promoted in university education, giving it its current characteristics related to informality and mediocrity. This forced the National Superintendece of University Education to start a licensing process for universities in 2015, i.e. they verify that universities comply with minimum standards for university education. In this process, 141 universities submitted their licensing request, but only 64 received the operating license until March 2019. This setback has reinforced the popular image of a nursing as a legal profession, but not a technical-scientific profession.

\section{Professional discomfort and stress}

Management teaches that one of the keys of performance is aligning the staff with the mission, vision and strategies of the entity, which is true. However, in this case, "the health system is not the only with Human Resource problems; the human resources also have problems with the health system:" ${ }^{30} 23.6 \%$ of nurses think that the Peruvian health care service is worse than before; $44.5 \%$ think it is the same; and only $31.9 \%$, that it has improved. The nurses' dissatisfaction with their work situation reaches $36.1 \%$ with respect to the salaries received, $30.2 \%$ due to the limited training opportunities, and $23.1 \%$ due the disorder of the services and work organization, and $22.3 \%$ due the limited possibility of job promotions or raises. $42.9 \%$ is dissatisfied with the human resources management ${ }^{26}$.

In this context of services without resources and organization, the nursing job becomes difficult. $31.7 \%$ has suffered aggressions in their job during the last 12 months, either by patients or by their relatives. 39.8\% suffered aggressions working in admission, $37 \%$ in emergencies, and $21 \%$, in outpatient consultation. $18.7 \%$ of nurses state they have been threatened in their workplaces, whereas $25.3 \%$ of nurses say they have suffered an illness that has been caused and/or aggravated by their job $^{26}$. Considering all this, $17.6 \%$ of nurses have once thought of changing jobs ${ }^{26}$.

Nurses often deal with situations that produce work-related stress. In the 2014 National Survey, $27.5 \%$ stated that they felt emotionally drained at times during the year, 33\% claimed that their job was wearing them out, and $22.6 \%$ said that they felt frustrated at work. Therefore, $18.5 \%$ of nurses have displayed depressive symptoms for several days in the previous two weeks. Santiago-Ullero et al. ${ }^{31}$ found in 2015 that $4.9 \%$ of the sample of physicians and nurses living in Lima Metropolitana had the intention to migrate to the interior and that there was an association between perceived stress and the intention to migrate. Marticorena et al..$^{32}$ found a global prevalence of job burnout of $2.8 \%$ using predetermined values; of $7.9 \%$ for cut points according to quartiles; and $12.5 \%$, using tertiles. This phenomenon is not exclusive of Peru. Alilu et al..$^{33}$ discovered in hospital nurses in Iran that the "social image of nursing" and the "culture and structure of nursing care for bedridden patients" mostly explained the motivation of nurses to abandon the care of hospital patients. Lagerlund et al..$^{34}$ found in Sweden that about one third of nurses planned to 
leave their work centers the following year and that this percentage was higher among those who perceived a lack of leadership in the service, no adequate training for cancer patients, and high burnout rates. Leineweber et al. ${ }^{35}$ studied in 384 hospitals in ten countries the intention to leave the profession $(4.6 \%)$ and the intention to leave the current workplace (6.9\%), finding that it was associated with the work environment and flexible schedules. What is special about Peruvian nursing with respect to the discomfort at work is how simple it is for them to consider migrating out of the country.

\section{Propensity to migration}

Peruvian nurses are the ones who migrate the most, compared to the nurses of the region. In 2011, they exceeded the number of nurses from all South American countries ${ }^{36}$. According to the National Statistics Institute, 18,198 nurses migrated between 1990 and 2015, which represents $7.9 \%$ of the total number of professional migrants of Peru ${ }^{37}$.

The main destination countries were Italy, the United States and Spain. Existing statistics reveal that $43.6 \%$ were between 21 and 31 years old when they traveled and that they migrated for family reasons: $39.8 \%$; in search of economic improvement: $34.2 \%$; and to study: $15.3 \%$. A total 97.7\% were female nurses. However, not all migrating nurses are working exclusively as nurses abroad: $22.7 \%$ of the total stated to be students; $13.6 \%$ were office employees; and $10.9 \%$ were homemakers, among other occupations. Nonetheless, $79.2 \%$ managed to fit in the destination country, and $95.6 \%$ would recommend migrating. $54.4 \%$ has stayed abroad for over seven years, and does not have a return date ${ }^{38}$. This means that the national educational system covers the internal demand and part of the global demand regarding professional caretakers. Retention of human resources becomes a priority, since the investment in human capital is being donated abroad.

\section{Scenarios: Exit, Voice, and "Loyalty"}

Peruvian nursing arrives at the second decade of the 21st Century with the following characteristics: a) a large workforce mostly located in the public sector, b) a tendency to redistribute to poor regions, c) a steady presence by levels of health care, d) a very large operating force, which organizes health care services, e) overcrowding in undergraduate programs, mostly the private ones, f) an over-supply of graduates, g) an expansion of graduate studies and specialization training, h) scarce relevant research, i) low salaries, j) low social legitimacy, $\mathrm{k}$ ) job dissatisfaction, and l) a relatively high proportion of migrants abroad.

What connects all these elements of the current profile of nursing is that they are signs of an entropic system, that is, of a system without order, with a broken homeostasis, which works at the cost of losing capacities and not reaching the potential achievements ${ }^{39}$. The new balance point is of low level. The professionals involved and the users of the system pay with avoidable morbidity and mortality the work and psychological overload of this anomalous system. The model continues working, but the regular abnormality has installed itself. We are facing a classic dilemma of collective action. If entropy reaches the extremes of physical and psychological abuse, the resilience of the actors is not enough. At this level, the three classic Hirschman options emerge: exit, voice, or loyalty ${ }^{40}$. Each profession chooses its strategy to mitigate damages. In terms of the future scenarios for Peruvian nursing, there are also three: resilience, abandonment, and reaction.

Resilience represents the adaptation to this unfavorable situation, the willingness to pay the high cost arising from these conditions. For many professionals, it is accepting the situation as inevitable even though it means to incorporate the low status assigned as self-identity. Today, Peruvian nursing is facing a dilemma: either it becomes an informal nursing or it develops as a technical-scientific nursing. The resilience reconciles with the first one, accepting the de-professionalization that implies maintaining the universities of questionable quality and the social disregard of their work.

Behind the salaries assigned in the public sector to nursing is the will to avoid that as a social group be from the middle classes and rather be located in socioeconomic levels $\mathrm{C}$ and $\mathrm{D}$. The compensation of professions in Peru is still aristocratic. And that perception is fed by the fact that nursing never had the status of an independent profession because it turned in the middle of the 20th century from a parareligious occupation to a state-run profession, unlike physicians who did have a period of being independent professionals before moving on to payroll positions in the 1960s. This marks professions socially and culturally since independent professionals in the traditional society were always an essential part of the middle classes ${ }^{41}$. Though in the history of Peruvian nursing, socio-economic levels A and B 
stopped being attracted to nursing when it went from an amateur volunteering to a profession taught in schools, which was later compensated. Since then, it has experienced some form of exclusion and in some cases, it has responded by excluding itself and internalizing social stigma as a professional identity.

Abandonment is the exit of the country or the profession. Thousands of nurses migrate, or seek other occupations. The 2016 survey revealed that $25.7 \%$ of the nurses currently working in the health care sector have migration in their plans. Regarding institutions, MINSA nurses account for 28.7\%; while EsSalud nurses, 22\%. Among physicians, this average is higher: $34.8 \%$. However, in all cases, these figures are unusual for a profession. Peruvian nursing has 18,000 professionals abroad and 44,000 active professionals in the country. This migrant bracket was not able to adapt to the situation.

Reaction is the third option. This is the profession's manifestations against surrendering to informality and mediocrity. Now there is a na- tional movement of Peruvian nursing for the techno-scientific qualification of the profession, with specialties and graduate degrees. Today, $59.6 \%$ of nurses have some specialty ${ }^{26}$. Fifteen years ago, there were no nurses with a specialty. Part of this positive reaction is also the licensing and accreditation of the Nursing Schools and Departments. This bracket choose to respond to the unfavorable situation. Given the fact that there is a difference between professionalization and professionalism ${ }^{2}$, and legal professionalization is almost already completed, now the challenge is to assume professionalism, which will bring higher legitimacy, scientific development and autonomy. The profession needs to overcome the public image of an empirical occupational group. The literature tells us that professionals adapt to professional cultures containing behavior codes, rituals, standards and values. The power of public opinion in the formation of professional identities is great ${ }^{10}$; therefore, a non-adaptive behavior is necessary to construct a new professionalism. This is their current historical challenge.

\section{Acknowledgements}

To Yesenia Musayón, Gianina Farro, Natali Loncherich, Mistral Carhuapoma Acosta, Nélida Hilario, María del Carmen Salazar and José Grados, nursing professionals for sharing their knowledge and experience with the author. 


\section{References}

1. Tavera F. Historia de la Escuela Nacional de Enfermeras Arzobispo Loayza. $2^{\text {nd }}$ ed. Lima: Universidad Peruana Cayetano Heredia; 2015.

2. Abbott P, Meerabeau L. The Sociology of the Caring Professions. $2^{\text {nd }}$ ed. London and Philadelphia: University College London Press; 2003.

3. Fraser N. From Redistribution to Recognition? Dilemmas of Justice in a 'Post-Socialist' Age. New Left Review 1995; 212(1):68-93.

4. Freidson E. Profession of Medicine. A Study of Sociology of Applied Knowledge. New York: Harper \& Row, Publishers, Inc; 1970.

5. Abbott A. The system of professions. An essay on the division of expert labor. Chicago: University of Chicago Press; 1988.

6. Machado MH. Sociología de las profesiones: un nuevo enfoque. Educ Med Salud 1991; 25(1):28-36.

7. Turner C, Hodge MN Ocuppations and professions. In: Jackson JA. Professions and professionalization. Cambridge: Cambridge University Press; 2010.

8. Etzioni A. The semi-professions and their organisation. New York: Free Press; 1969.

9. Moloney MM. Professionalization of Nursing, Current Issues and Trends. Philadelphia, PA: J.B. Lippincott Co.; 1992.

10. Emami A, Nasrabadi AN. Two approaches to nursing: a study of Iranian nurses. Int Nurs Rev 2007; 54:137143.

11. Hudson B. Pessimism and optimism in inter-professional working: The Sedgefield Integrated Team. J Interprof Care 2007; 21(1): 3-15.

12. Ministry of Health of Peru. Información de Recursos Humanos en el Sector Salud, Perú 2017. Lima: Ministry of Health; 2017.

13. Arroyo J. Situación y desafíos de los recursos humanos en salud. Lima: Ministry of Health of Peru; 2006.

14. Instituto Nacional de Estadística e Informática (INEI). Establecimientos del sector salud [Internet]. [cited 2019 March 21]. Available in: https://www.inei. gob.pe/estadisticas/indice-tematico/health-sector-establishments/\#url

15. McClain L. Care as a Public Value: Linking Responsibility, Resources, and Republicanism. Chic Kent Law Rev 2001; (76)3:1673-1731.

16. Instituto Nacional de Estadística e Informática (INEI). Cuenta satélite de trabajo doméstico no remunerado. Lima: INEI; 2016.

17. Instituto Nacional de Estadística e Informática (INEI). Perú, Condiciones de empleo e ingreso por departamento, 2007-2017. Lima: INEI; 2018.

18. Aguirre R. El futuro del cuidado. In: Arriagada I, organizadora. Futuro de las familias y desafíos para las políticas. Santiago de Chile: CEPAL; 2008. p. 23-35.

19. Marzouk MS. Aging, Age-Specific Health Care Costs and the Future Health Care Burden in Canada. Can Public Policy 1991; (17)4:490-506.

20. Hennessy M. Factcheck: Are Irish nurses among the highest paid in the world? [Internet]. 2019 [cited 2019 March 21]. Available from: https://www.thejournal.ie/ factcheck-nurses-pay-4463814-Jan2019/
21. Boniol M, McIsaac M, Xu L, Wulij T, Diallo K, Campbell J. Gender Equity in the health workforce: analysis of 104 countries. Working paper 1. Geneva: WHO; 2019.

22. Sal y Rosas V, Moscoso-Porras M, Ormeño R, Artica F, Bayes C, Miranda J. Gender income gap among physicians and nurses in Peru: a nationwide assessment. Lancet Glob Health 2019; 7:412-413.

23. Ministerio de Trabajo y Promoción del Empleo del Perú. Portal Ponte en Carrera.pe [Internet]. [cited 2019 March 21]. Available from: https://www.ponteencarrera.pe/

24. Instituto Nacional de Estadística e Informática (INEI). Number of nurses broken down by department, 2009-2017. Colegio de Enfermeros del Perú; 2017.

25. Ministry of Health of Peru (MINSA). Compendio Estadístico de Recursos Humanos del Sector Salud 20102016. Lima: MINSA; 2016.

26. SUSALUD. Encuesta Nacional de Satisfacción de Usuarios en Salud 2016. Lima: INEI; 2016.

27. Musayón Y. Aulas perdurables, cien años en la formación de enfermeras. Lima: Universidad Peruana Cayetano Heredia; 2017.

28. Díaz J. Educación superior en el Perú: tendencias de la demanda y la oferta. In: Benavides M. Análisis de programas, procesos y resultados educativos en el Perú: contribuciones empíricas para el debate. Lima: GRADE 2008. p. 83-129.

29. Jimenez MM, Mantilla E, Huayanay-Espinoza CA, Gil K, García H, Miranda JJ. Mercado de formación y disponibilidad de profesionales de ciencias de la salud en el Perú. Rev Peru Med Exp Salud Publica 2015; 32(1):41-50.

30. Arroyo J, Hartz J, Lau M. Recursos Humanos en Salud al 2011. Evidencias para toma de decisiones. Lima: MINSA; 2011.

31. Santiago-Ullero B, Valer-Villanueva S, Urrunaga-Pastor D, Benites-Zapata V. Estrés percibido e intención de migrar al interior del país en médicos y enfermeros que residen en Lima: un análisis exploratorio de la encuesta nacional de satisfacción de usuarios en salud (ENSUSALUD), 2015. Rev Peru Med Exp Salud Publica 2017; (34)3:404-413.

32. Maticorena-Quevedo J, Beas R, Anduaga-Beramendi A, Mayta-Tristán P. Prevalencia del síndrome de burnout en médicos y Enfermeras del Perú, ENSUSALUD 2014. Rev Peru Med Exp Salud Publica 2016; (33) 2:241-247.

33. Alilu L, Zamanzadeh V, Valizadeh L, Habibzadeh H, Gillespie M. A Grounded theory study of the intention of nurses to leave the profession. Rev Lat Am Enfermagem 2017; 25:e2894.

34. Lagerlund M, Sharp L, Lindqvist R, Runesdotter S, Tishelman C. Intention to leave the workplace among nurses working with cancer patients in acute care hospitals in Sweden. Eur J Oncol Nurs 2015; 19:629-637.

35. Leineweber C, Chungkham HS, Lindqvist R, Westerlund H, Runesdotter S, Alenius LS, Tishelman C. Nurses' practice environment and satisfaction with schedule flexibility is related to intention to leave due to dissatisfaction: A multi-country, multilevel study. Int J Nurs Stud 2016; 58:47-58. 
36. Pan American Health Organization (PAHO). Nurses migration in Latin America. South American Area. Washington D.C.: PAHO; 2011.

37. Instituto Nacional de Estadística e Informática (INEI). Perú: Estadística de la emigración internacional de peruanos e inmigración de extranjeros, 1990-2015. Lima: INEI; 2016.

38. Organización Panamericana de la Salud (OPS). Migración de enfermeras en América Latina. Washington D.C.: OPS; 2011.

39. Hintze J. La desorganización óptima. Rev CLAD Reforma y Democracia 2008; 42:131-172.

40. Hirschman A. Exit, Voice and Loyalty. Responses to Decline in Firms, Organizations, and States. Massachusetts and London: Harvard University Press; 1970.

41. González L. La independencia de las profesiones liberales. Revista de Estudios Políticos 1960: 147-158.

Artigo apresentado em 13/04/2019

Aprovado em 20/08/2019

Versão final apresentada em 04/09/2019 